\title{
Eksistensi Partai Politik Dalam Persepsi Publik The Existence of The Political Parties in Public Perception
}

\author{
Efriza* \\ ${ }^{*}$ Dosen llmu Politik, Sekolah Tinggi Ilmu Pemerintahan Abdi Negara \\ email: efriza.riza@gmail.com
}

Riwayat Artikel

Diterima 15 Maret 2019

Direvisi 21 April 2019

Disetujui 2 Mei 2019

\begin{abstract}
A democratic country needs political parties. They become the driving force in the implementation of democracy in Indonesia considering the important role that they play in various political processes in the legislature, government, and other state institutions. Given the importance of political parties in Indonesia in the Reform era, it turns out that most problems come from political parties. This paper aims to gain an understanding of the development and role of political parties in the Reform era based on the public perception of the existence of political parties. Based on the objective of the study, the significance of this study can hopefully be elicited, which is to provide an understanding and an input on the development and role of political parties in the Reform era. Results of the study suggests that public perception of the performance of political parties as political infrastructure was still poor and that political parties were also responsible for the poor performance of the political superstructure institutions. Therefore, the researcher recommends that political parties internally need to strengthen party institutionalization, while on the other hand, there needs to be an effort to simplify party systems in Indonesia.
\end{abstract}

Keywords: Political Parties; Democracy; Reform; Public Perception. 


\section{Pendahuluan}

Sebuah negara demokratis membutuhkan adanya partai politik dan pemilihan umum (Pemilu). Keberadaan partai politik semakin penting karena demokrasi mensyaratkan wewenang warga untuk memerintah dan menjadi bagian dari hak warga berpartisipasi menentukan kebijakan publik dan pemimpin. Tetapi partai politik dibuat tidak hanya untuk memerintah. Partai politik juga untuk menyalurkan collective will-merepresentasikan kepentingan berbagai kelompok dalam masyarakat. ${ }^{1}$ Terkait dengan kebijakan publik, maka ada batasan yang lengkap mengenai partai politik seperti dikemukakan oleh Mark N. Hagopian bahwa, partai politik adalah suatu organisasi yang dibentuk untuk memengaruhi bentuk dan karakter kebijakan publik dalam kerangka prinsip-prinsip dan kepentingan ideologis tertentu melalui praktik kekuasaan secara langsung atau partisipasi rakyat dalam pemilu. $^{2}$

Begitu pentingnya Partai Politik, sehingga diasumsikan bahwa tak ada demokrasi tanpa partai politik, pernyataan ini cukup sering dikemukakan. Ini didasari oleh fakta bahwa institusi partai politik adalah salah satu pilar penting bangunan sistem demokrasi selain institusi pemilu, eksekutif, legislatif, yudikatif, dan lembaga pers yang bebas. ${ }^{3}$ Meski begitu pentingnya kedudukan partai politik dalam sistem demokrasi, tetapi tanpa partai politik yang kuat maka tak akan ada demokrasi yang kuat. $^{4}$

Partai politik pada awalnya dibentuk atas dasar keinginan untuk menyatukan berbagai

1 Antonio Pradjasto, "Partai Politik tak Hanya Kemampuan Memerintah," Jurnal Jentera, no. 16, (Juni 2007), 26

2 Ichlasul Amal, ed., Teori-teori Partai Politik (Edisi Revisi), (Yogyakarta: Tiara Wacana Yogya, 1996), xv

3 Syamsuddin Haris, Partai, Pemilu, dan Parlemen Era Reformasi (Jakarta: Yayasan Pustaka Obor Indonesia, 2014), 45

4 Sebastian Salang, Potret Partai Politik di Indonesia: Assemen terhadap Kelembagaan, Kiprah, dan Sistem Kepartaian (Jakarta: Freiedrich Naumann Stiftung, 2007), v kelompok masyarakat yang mempunyai visi dan misi yang sama, sehingga pikiran dan orientasi mereka dapat dikonsolidasikan. Berangkat dari hal tersebut, dapat diuraikan bahwa partai politik merupakan kelompok terorganisir, yang anggota-anggotanya mempunyai orientasi, nilai-nilai, dan cita-cita yang sama, yang bertujuan untuk mewujudkan cita-cita tersebut dalam bentuk program yang akan dilaksanakannya dengan cara konstitusional untuk memperoleh kekuasaan politik dan merebut kedudukan politik. ${ }^{5}$

Penafsiran di atas, jelas mencerminkan bahwa faktor ideologi tak bisa diabaikan, sebab partai politik mesti memiliki ideologi yang berfungsi tak hanya sebagai identitas pemersatu, ${ }^{6}$ serta juga memberikan karakter tersendiri yang dapat menjelaskan mengapa suatu partai harus ada, dan karakter perbedaan antar partai-partai politik, di samping itu ideologi juga sebagai tujuan perjuangan partai. Di banyak sistem demokrasi, keberadaan ideologi tersebut diturunkan dalam manifesto dan program partai yang tentu juga berbeda dengan partai lainnya. Perbedaan program kerja partai ini memudahkan masyarakat untuk menentukan pilihannya, program kerja mana yang sesuai dengan keadaan hidup masyarakat itu sendiri, dan program kerja partai tentunya akan menjadi sikap dasar partai dalam proses pengelolaan kebijakan negara. ${ }^{7}$

Penjelasan di atas telah menunjukkan bahwa betapa pentingnya partai politik sebagai suatu sarana untuk manusia atau warga negara dalam membentuk suatu organisasi dengan tujuan mewujudkan aspirasinya, yang kemudian diwujudkan dengan fungsi-fungsi politik itu sendiri. Secara umum fungsi partai politik dapat dikelompokkan menjadi empat

5 Miriam Budiardjo, Dasar-dasar Ilmu Politik, (Jakarta: Gramedia, 2008), 404

6 Ramlan Surbakti, Memahami Ilmu Politik, (Jakarta: Grasindo, 1992), 115

7 Pramono Anung Wibowo, Mahalnya Demokrasi Memudarnya Ideologi: Potret Komunikasi Politik LegislatorKonstituen (Jakarta: Kompas, 2013), 272-273

Efriza: Eksistensi Partai Politik Dalam Persepsi Publik 
fungsi utama. Keempat fungsi utama tersebut yakni: artikulasi dan agregasi kepentingan, pendidikan politik, kaderisasi, dan rekrutmen. Antara fungsi yang satu dengan fungsi yang lainnya memiliki keterkaitan, dan memiliki pengaruh besar terhadap ekspektasi dan animo anggota maupun masyarakat umum terhadap suatu partai politik. ${ }^{8}$

Dalam perkembangan partai politik di Indonesia pada awal runtuhnya Orde Baru, keran kebebasan politik masyarakat terbuka luas, sehingga diikuti menjamurnya partai politik sebagai akibat dari pembelengguan politik yang terjadi semasa rezim itu berkuasa. Menariknya hingga sekarang ini, kebangkitan partai politik masih menonjol, malah dianggap bahwa kita terjebak oleh perangkap partycracy (kedaulatan di tangan partai) ketimbang demokrasi (kedaulatan di tangan rakyat). Partycracy memungkinkan pengendalian atas minimal dua lembaga, yakni kepresidenan (termasuk kepala-kepala daerah) dan parlemen (nasional dan lokal). Dua lembaga itu memiliki hak konstitusional, mulai dari regulasi sampai implementasi, termasuk perekrutan sumber daya manusia. ${ }^{9}$

Nyatanya, kebangkitan partai politik di era reformasi malah menimbulkan paradoks. Di satu sisi, Undang-Undang Dasar (UUD) 1945 yang merupakan konstitusi bangsa telah menyiratkan peran partai politik sebagai institusi penentu keberlangsungan hidup bangsa dan negara. Sebab di tangan partai politik, dan bukan institusi lain, sebenarnya siapa-siapa saja yang akan mengendalikan bangsa ini ditentukan. Misalnya, hanya pada partai politik terletak hak mengusulkan Pasangan Presiden dan Wakil Presiden (Pasal 6A ayat (2)) dan hanya institusi inilah yang menjadi peserta pemilu untuk mencalonkan para wakil rakyat yang duduk dalam Dewan Perwakilan Rakyat (DPR) dan Dewan Perwakilan Rakyat Daerah

\footnotetext{
8 Salang, Potret Partai Politik, 8

9 Indra J. Pilliang, "Kebangkitan 'Partycracy," Koran Jakarta, 27 September 2014, 4
}

(DPRD) seperti diatur dalam Pasal 22E ayat (3). Selain itu, secara yuridis, partai politik memiliki posisi kuat karena keputusan pembubaran sebuah partai politik tidak bisa sembarangan diputus pemerintah, melainkan harus melalui keputusan Mahkamah Konstitusi (MK) diatur dalam Pasal 24C ayat (1). ${ }^{10}$ Namun, di sisi lain, dalam hubungan dengan masyarakat, bahwa partai politik acapkali menjadi sebuah institusi yang dicurigai dan bahkan dijauhi. Perkembangan dewasa ini mengarah pada situasi yang mana sebuah institusi penentu yakni partai politik, nampak menjelma sebagai lembaga yang semakin tidak dipercayai oleh publik. ${ }^{11}$ Asumsi itu menyembulkan pertanyaan besar dalam penelitian ini, Bagaimana perkembangan dan peran partai politik pada era reformasi ini? Dan, Bagaimana persepsi publik terhadap peran partai politik di era reformasi ini?

\section{Metode Penelitian}

Penulisan ini merupakan sebuah kajian untuk memahami tentang perkembangan dan peran partai politik di era reformasi dalam persepsi masyarakat atas eksistensi partai politik. Agar dapat memperoleh jawaban dari permasalahan dalam penulisan ini, maka penulisan ini dirancang dengan pendekatan kualitatif dengan jenis penelitian menggunakan metode studi pustaka (library research). Teknik pengumpulan data dilakukan dengan mengadakan studi penelaahan terhadap buku-buku, literatur-literatur, surat kabar, majalah, dan laporan-laporan yang ada hubungannya dengan masalah dalam kajian ini. ${ }^{12}$ Dalam melakukan prosedur

10 Rully Chairul Azwar, "Partai Politik Di Tengah Ancaman "Virus" Oligarki dan Politik Kartel," Jurnal Ketatanegaraan, no. 5 (November 2017), 2

11 Firman Noor, Quo Vadis Demokrasi Kita? Sebuah Respon Terhadap Konsolidasi Demokrasi Indonesia (Jakarta: RMBooks, 2015), 3

12 Lihat, M. Nazir, Metode Penelitian (Jakarta: Ghalia Indonesia, 2003); dan pelajari juga, Suharsimi Arikunto, Prosedur Penelitian Suatu Pendekatan Praktek (Edisi Revisi), (Jakarta: Rineka Cipta, 2002). 
studi pustaka bahwa informasi-informasi yang dihimpun dari sumber kepustakaan adalah yang relevan dengan kajian dari penulisan ini, termasuk juga dalam penelitian ini akan diuraikan data-data yang dihasilkan dari lembaga-lembaga survei untuk menjelaskan mengenai persepsi masyarakat terhadap peran dari partai politik di era reformasi ini. Sehingga demikian, dari penulisan ini dapat diuraikan tujuan yang ingin dihasilkan yakni untuk memperoleh pemahaman mengenai perkembangan dan peran partai politik di era reformasi berdasarkan persepsi masyarakat atas eksistensi partai politik. Dari tujuan itu maka diharapkan dapat dihasilkan kegunaan kajian ini, bahwa kajian ini diharapkan dapat memberikan pemahaman dan masukan terhadap perkembangan dan peran partai politik di era reformasi ini. Berdasarkan uraian-uraian di atas, bahwa dalam melakukan kajian ini diharapkan penulisan ini dapat dihasilkan temuan kebaruan dari hasil proses penulisan ini.

\section{Partai Politik Secara Konsep}

Mendefinisikan partai politik tidaklah sederhana. Mendefinisikan partai politik umumnya bersifat normatif dan jawaban yang diberikan oleh para ilmuwan politik berbeda-beda dari waktu ke waktu. Tetapi, ada anggapan umum mengenai partai politik yang berangkat dari anggapan bahwa dengan membentuk wadah organisasi mereka bisa menyatukan orang-orang yang mempunyai pikiran serupa sehingga pikiran dan orientasi mereka bisa dikonsolidasikan. Dengan begitu pengaruh mereka bisa lebih besar dalam pembuatan dan pelaksanaan keputusan. ${ }^{13}$

Meski banyak definisi-definisi partai politik namun beberapa contoh dikemukakan sebagai berikut. Menurut Edmund Burke dikutip oleh Katz dan Crotty bahwa, "Partai politik adalah sekumpulan orang yang bersatu untuk memperjuangkan kepentingan nasional melalui usaha bersama mereka, berdasarkan pada prinsip-prinsip tertentu yang mereka semua sepakati”. ${ }^{14}$ Sedangkan, menurut Giovanni Sartori bahwa, "Partai politik adalah suatu kelompok politik yang mengikuti pemilihan umum dan melalui pemilihan umum itu, mampu menempatkan calon-calonnya untuk menduduki jabatanjabatan publik". ${ }^{15}$

Dari hadirnya partai politik ini yang penting dipahami adalah meluasnya gagasan bahwa rakyat harus diikutsertakan dalam proses politik maka partai politik telah lahir, dan berkembang menjadi penghubung penting antara rakyat dan pemerintah. Pernyataan itu, serupa dengan yang diungkapkan oleh Alexandra Cole bahwa, "Pembentukan partai politik pada umumnya dikaitkan dengan upaya memperluas kepentingan dan pemerintahan representatif". ${ }^{16}$ Partai politik juga dianggap sebagai perwujudan atau lambang negara modern. Bahkan, arti penting partai politik diungkapkan Richard M. Merelmen dalam kata-kata puitis dalam kata pendahuluan buku: "Party Politics and Pressure Groups A Comparative", yang ditulis Maurice Duverger. Bahwa, "dari semua alat yang pernah didesain oleh manusia untuk mencapai tujuan-tujuan politiknya, barangkali tidak ada yang lebih ampuh dari partai politik. Memang benar, politik modern tanpa partai politik sama saja dengan ikan yang berada di luar air". ${ }^{17}$

Meski begitu, batasan yang lebih lengkap mengenai partai politik seperti telah dijelaskan di atas, yaitu dikemukakan oleh Mark N. Hagopian bahwa, "Partai politik adalah suatu organisasi yang dibentuk untuk memengaruhi

14 Richard S. Katz dan William Crotty, Handbook Partai Politik (Bandung: Nusamedia, 2015), 4

15 Budiardjo, Dasar-Dasar Ilmu Politik (Edisi Revisi), 404

16 Alexandra Cole, Perbandingan Partai Politik: Sistem dan Organisasi, di Ilmu Politik Dalam Paradigma Abad Ke-21 (Jilid 1), ed. John T. Ishiyama dan Marijke Breuning, (Jakarta: Kencana, 2013), 249

17 Maurice Duverger, Partai Politik dan Kelompok-kelompok Penekan, penerj. Laila Hasyim, (Bina Aksara, 1984), v

Efriza: Eksistensi Partai Politik Dalam Persepsi Publik 
bentuk dan karakter kebijaksanaan publik dalam kerangka prinsip-prinsip dan kepentingan ideologi tertentu melalui praktik kekuasaan secara langsung atau partisipasi rakyat dalam pemilihan". 18

Batasan-batasan tersebut, tampak jelas bahwa basis sosiologis suatu partai adalah ideologi dan kepentingan yang diarahkan pada usaha-usaha untuk memperoleh kekuasaan. Jika batasan ini diberikan penafsiran, maka misalnya, penulis menggunakan pendapat dari Ramlan Surbakti bahwa, ideologi merupakan hal terpenting bagi partai politik, setiap partai politik mesti memiliki ideologi yang berfungsi tidak hanya sebagai identitas pemersatu, tetapi juga sebagai tujuan perjuangan partai. ${ }^{19}$

Dapat dikatakan bahwa partai politik itu merupakan salah satu bentuk organisasi politik di luar struktur negara dan mempunyai posisi sebagai struktur antara (intermediate-structure) di antara suprastruktur pemerintahan negara dengan infrastruktur kehidupan bersama dalam masyarakat. Fungsi partai politik juga sangat penting dalam kegiatan bernegara, yang biasa dirumuskan sebagai: pertama, sarana komunikasi politik dan penyerap aspirasi politik; kedua, sarana sosialisasi politik dan pendidikan politik; ketiga, sarana rekrutmen politik; dan keempat, sarana pengatur dan peredam konflik dalam masyarakat. ${ }^{20}$

Namun dalam perkembangannya, sangat disayangkan, bahwa kebanyakan partai politik modern menurut Andrew Heywood, ${ }^{21}$ masuk dalam kategori apa yang oleh Otto Kirchheimer diistilahkan sebagai 'catch all party' atau 'partai tangkap semua'.22 Istilah

18 Amal, ed., Teori-teori Partai Politik (Edisi Revisi), xv

19 Surbakti, Memahami Ilmu Politik (Jakarta: Grasindo, 1992), 115

20 Jimly Asshiddiqie, "Penguatan dan Penataan Partai Politik di Masa Depan,” Jurnal Ketatanegaraan, no. 5, (November 2017), 35

21 Andrew Heywood, Politik (Edisi Keempat), (Yogyakarta: Pustaka Pelajar, 2014), 393

22 Otto Kirchheimer, Transformasi Sistem-Sistem Kepartaian Eropa Barat, di Teori-teori Partai Politik (Edisi Revisi), ed. Ichlasul Amal, (Yogyakarta: Tiara Wacana Yogya, 1996) 'catch all party' ini menunjukkan bahwa partaipartai politik yang secara drastis mengurangi muatan ideologis mereka dalam rangka untuk memenuhi sebanyak mungkin jumlah pemilih dan kemenangan dalam pemilihan umum.

Partai catch all tidak lagi mendasarkan pada satu ideologi atau platfrom dalam menentukan sikap politik. Jika melihat kecenderungan tersebut pada partai catch all, maka spektrum legitimasi partai politik ini adalah pada pertimbangan rasional partai. Pusat-pusat kekuasaan dan kewenangan yang tersebar menjadikan pertimbangan rasional sebagai landasan penentuan keputusan-keputusan politik, dengan kata lain partai politik ini menempatkan pragmatisme di depan.

\section{Partai Politik Sebelum Era Reformasi}

Demokrasi, mempunyai aturan main yang mempercayakan produk-produk berupa keputusan kolektif, hal mana organisasi mempunyai tempat khusus. Dalam demokrasi, keputusan kolektif yang mengikat hanya bisa diraih lewat partisipasi. Partai politik adalah organisasi yang memiliki kegandaan hak dalam demokrasi: sebagai pemerintahan untuk rakyat dan dipilih oleh rakyat. Partai politik adalah representasi "aktor kolektif" dan legitimasi keputusannya hanya dapat dicapai melalui partisipasi. Partai sebagai "aktor kolektif" memungkinkan terbentuknya satu visi atas satu kekuasaan atas nama rakyat. Itulah sebabnya, penguasa otoriter pun dalam melegitimasikan kekuasaannya, turut menggunakan partai politik. ${ }^{23}$ Perkembangan partai politik di Indonesia turut menjelaskan hal tersebut.

Dalam perkembangan sejarah, bahwa likaliku perjalanan partai politik di Indonesia tidak bisa dilepaskan dari realitas pemilihan sistem kepartaian multipartai. Awal pembentukan organisasi modern terjadi segera sesudah

23 Pipit R. Kartawidjaja dan Mulyana W. Kusumah, Kisah Mini Partai Politik (Jakarta: Closs dan 7 Strategic Studies, 2003), 7-8 
adanya perubahan dalam kebijakan kolonial pada permulaan abad ke-20. Tidak bisa dibayangkan, apa yang bakal terjadi dengan Hindia Belanda tanpa kehadiran partai politik pada awal abad ke-20 tersebut. Jika sejarah dipahami sebagai proses, sebagai perjalanan kehidupan berbangsa, maka partai-partai yang bermunculan pada masa itu (termasuk Partai Komunis Indonesia (PKI) sekalipun) mempunyai andil besar dalam pembentukan negara dan bangsa ini. ${ }^{24}$

Pada era kolonial, partai-partai dibentuk untuk mencari dan merumuskan identitas nasional di satu pihak, dan dalam rangka memperkuatperjuanganmerebutkemerdekaan di lain pihak. Karena itu, tidak mengherankan jika ideologi-ideologi besar seperti Islamisme, Nasionalisme, dan Marxisme mendasari pembentukan partai pada periode kebangkitan nasional. Meskipun menjadi wadah aspirasi dari kelompok dan/atau golongan ideologis berbeda-beda, partai-partai pada era kolonial turut memberikan kontribusi bagi pencarian sekaligus "penemuan" identitas ke-Indonesiaan yang mendasari pembentukan republik. ${ }^{25}$

Perkembangannya peranan partai politik mengalami fluktuasi pada era setelah merdeka. Secara konvensional, era setelah merdeka atau sebelum Orde Baru Soeharto runtuh biasanya dibagi ke dalam tiga periode, yakni rezim Demokrasi Parlementer (1949-1959), Demokrasi Terpimpin (1959-1965), dan Demokrasi Pancasila atau yang dikenal dengan Orde Baru (1966-1998). Hal mana setelah kemerdekaan, partai-partai politik diberi ruang hidup seluas-luasnya sejak dikeluarkannya Maklumat Pemerintah tanggal 4 November 1945. Maklumat tersebut berisi bahwa "Pemerintah menyukai timbulnya partai-partai politik karena dengan adanya partai-partai itulah dapat dipimpin ke jalan yang teratur

24 Kartawidjaja dan Kusumah, Kisah Mini Partai Politik, 1

25 Syamsuddin Haris, Partai, Pemilu, dan Parlemen Era Reformasi (Jakarta: Yayasan Pustaka Obor Indonesia, 2014), 21 segala faham yang ada dalam masyarakat". Selanjutnya, Maklumat itu memuat bahwa pemerintah berharap supaya partai-partai itu telah tersusun sebelum dilakukan pemilihan anggota Badan Perwakilan Rakyat pada bulan Januari 1946.

Sejak keluarnya Maklumat itu maka berdirilah partai-partai politik. Umumnya partai-partai politik yang didirikan adalah kelanjutan dari organisasi-organisasi sosial dan partai politik yang sudah dibentuk pada masa kekuasaan kolonial Belanda dan kekuasaan pendudukan Jepang. Di antara partai politik yang berdiri adalah Masyumi, Partai Nasional Indonesia (PNI), Partai Komunis Indonesia (PKI) dan Partai Sosialis Indonesia (PSI) untuk menyebut beberapa partai yang penting.

Dalam pembentukan partai-partai politik, pengaruh ikatan primodial tampak jelas dalam pengorganisasian. Pengaruh ikatan-ikatan primodial, seperti agama, suku, dan kedaerahan, semakin terlihat dalam memengaruhi pengorganisasian partai politik. Hal ini dilakukan dalam rangka untuk mencari dukungan massa. ${ }^{26}$ Dapat dikatakan bahwa masa Demokrasi Parlementer adalah periode awal eksperimen demokrasi dengan tingkat dinamika kehidupan partai yang tinggi, bahkan dikenal sebagai era pemerintahan partai-partai. Dalam era ini partai politik memiliki peran yang begitu besar dalam setiap proses politik, di parlemen maupun di kabinet. Meski begitu, sayangnya partai politik digunakan hanya semata sebagai instrumen perjuangan untuk perebutan kursi atau jabatan sehingga yang terjadi adalah pemerintahan tidak pernah bertahan lama dan kabinet berganti-ganti. ${ }^{27}$

Pemikiran Soekarno tentang partai politik telah cukup jelas. Soekarno adalah seorang yang anti sistem multipartai model Barat dan sistem multipartai parlementer. Dalam pandangan Soekarno, partai politik memperlemah perjuangan terhadap penjajah

26 Sebastian Salang, Potret Partai Politik di Indonesia, 22

27 Haris, Partai, Pemilu, dan Parlemen Era Reformasi, 21

Efriza: Eksistensi Partai Politik Dalam Persepsi Publik 
dan usaha-usaha mengisi kemerdekaan. Partai politik adalah sumber perpecahan. Pandangan yang berbeda-beda di antara partai politik akan memecah belah bangsa. Kecenderungan partai politik untuk merebut kekuasaan politik menghasilkan konflik politik yang hebat di dalam masyarakat.

Penggunaan kabinet parlementer semenjak Oktober 1945 dan sistem multipartai semenjak November 1945 tidak membuat Soekarno memprotes tindakan tersebut, padahal pergantian sistem kabinet presidensial menjadi kabinet parlementer jelas melanggar Undang-Undang Dasar 1945 (UUD 1945), bahkan UUD 1945 tidak pernah dilakukan perubahan. Demikian juga dengan penggunaan kabinet parlementer dan sistem multipartai dalam Undang-Undang Dasar Sementara (UUDS 1950) tidak membuat Soekarno menentang semenjak awal. Setelah berjalan selama tiga tahun, barulah Presiden Soekarno mulai bersuara menuntut pembubaran partai politik.

Praktik-praktik kabinet parlementer dan sistem multipartai selama periode 1950-1957 telah menghasilkan ketidakstabilan politik karena konflik politik antar partai politik yang hebat. Hal tersebut kemudian ditambah dengan adanya pergolakan di daerah-daerah yang melahirkan konflik bersenjata. Oleh karena itu, ada alasan yang kuat bagi Soekarno untuk berkata bahwa kabinet parlementer dan sistem multipartai telah terbukti tidak cocok dengan bangsa Indonesia. Karena itu konsepkonsep yang berasal dari Barat tersebut harus ditinggalkan. ${ }^{28}$

Seiring dengan melemahnya demokrasi konstitusional di Indonesia, Presiden Soekarno melaksanakan idenya untuk membentuk kekuatan politik non-partai politik yang akan digunakan untuk mengimbangi partai politik. Kekuatan politik non-partai politik adalah golongan fungsional (kemudian berkembang

28 Salang, Potret Partai Politik di Indonesia, 23 menjadi Golongan Karya atau Golkar) dan militer yakni Angkatan Bersenjata Republik Indonesia (ABRI). Rencana untuk memperkuat kekuatan politik nonpartai politik disertai dengan rencana yang sistematis untuk memperlemah partai politik sebagai organisasi dan sebagai bagian pembuat kebijakan politik (decision maker).

Peranan politik Presiden Soekarno yang semakin membesar semenjak 1957 mencapai puncaknya dengan Dekrit Presiden 5 Juli 1959. Setelah dekrit tersebut, Soekarno dengan leluasa mendikte partai-partai politik dengan menjadi penguasa mutlak yang menentukan komposisi Majelis Permusyawaratan Rakyat Sementara (MPRS), Dewan Perwakilan Rakyat Gotong Royong (DPRGR), dan DPAS (Dewan Pertimbangan Agung Sementara). Partai-partai politik tidak berfungsi, bahkan jumlahnya dikurangi. Dari 28 partai politik, hanya tinggal 10 Partai yaitu: PNI, PKI, Partai Syarikat Islam Indonesia (PSII), Perti (Persatuan Tarbiyah Indonesia), Nahdlatul Ulama (NU), Partai Katolik, Partai Kristen Indonesia (Parkindo), Ikatan Pendukung Kemerdekaan Indonesia (IPKI), Musyawarah Rakyat Banyak (Murba), dan Partai Indonesia (Partindo). Dengan demikian, kehidupan politik dan kepartaian mutlak dikuasai oleh Soekarno. ${ }^{29}$

Keberlangsungan Demokrasi Terpimpin ternyata tidak berumur panjang. Benar apa yang dikatakan oleh Hatta bahwa Demokrasi Terpimpin bagaikan rumah kertas, yang tidak akan berumur panjang. Akibat tragedi Gerakan 30 September/Partai Komunis Indonesia (G 30S/PKI), Soekarno jatuh dari kursi kepresidenan. Meskipun oleh MPRS Soekarno telah diangkat menjadi Presiden seumur hidup, tetapi MPRS kemudian mencabut ketetapannya. MPRS menolak pertanggungjawaban yang diberikan Soekarno. Dengan demikian maka mandat MPRS terhadap Soekarno dicabut. Dengan

29 Salang, Potret Partai Politik di Indonesia, 23-24 
diberhentikannya Soekarno maka tamatlah Demokrasi Terpimpin, terkubur bersama penggagasnya. ${ }^{30}$

Periode Demokrasi Terpimpin kemudian digantikan dengan Demokrasi Pancasila oleh Pemerintah Orde Baru. Meski begitu, Demokrasi Terpimpin Soekarno dan Orde Baru Soeharto, sama-sama menunjuk pada era pemerintahan otoriter yang ditandai merosotnya peranan partaipartai dan menguatnya peranan militer. Pada era Demokrasi Terpimpin, peranan partai politik semakin termarginalkan, Soekarno mengatur pengakuan dan pengawasan terhadap partai politik. Jumlah partai politik di era Demokrasi Terpimpin ini dipangkas dan ideologi yang diperbolehkan hanya ada tiga yaitu Nasionalis, Agama, dan Komunis (Nasakom). Marginalisasi partai politik terus berlangsung hingga era Orde Baru, hal mana Soeharto hanyalah penerus visi Soekarno tentang partai politik. Kecurigaan dan ketidakpercayaan terhadap partai politik tetap dipertahankan oleh elite politik Orde Baru. ${ }^{31}$

Orde Baru melihat bahwa biang kekacauan yang mengganggu stabilitas politik, antara lain, adalah partai-partai politik. Partai-partai politik dianggap berperan mengganggu stabilitas. Hal ini karena berdasarkan pengalaman Demokrasi Parlementer hal mana pemerintah selalu berganti-ganti diakibatkan ulah partaipartai politik. Sehubungan dengan itu langkah yang dilakukan Orde Baru adalah melakukan penyederhanaan jumlah partai politik.

Dalam perkembangannya, kesembilan partai politik yang ada (Parmusi, NU, PSII, Perti, PNI, Partai Katolik, Parkindo, IPKI, dan Murba) dikelompokkan atas dua kelompok, yaitu: pertama, kelompok materiil-sprituil yang terdiri dari PNI, IPKI, Partai Katolik, Parkindo, dan Murba; dan kedua, kelompok sprituil-

30 Lili Romli, Mencari Format Sistem Kepartaian Masa Depan, Jurnal Politika, no. 2, (2006), 20

31 Maswadi Rauf, "Partai Politik dan Sistem Kepartaian di Indonesia Antara Kenyataan dan Harapan," Jurnal Politika, no. 2, (2006), 9, dan Eep Saefulloh Fatah, Pengkhianatan Demokrasi ala Orde Baru: Masalah dan Masa Depan Demokrasi Terpimpin Konstitusional, (Bandung: Remaja Rosdakarya, 2000), 194 materiil yang terdiri dari Parmusi, NU, PSII, dan Perti. Setelah Pemilu 1971, tepatnya tahun 1973, kedua kelompok tersebut diharuskan melakukan fusi. Kelompok pertama, yang terdiri dari partai-partai Islam, tergabung dalam wadah Partai Persatuan Pembangunan (PPP). Kelompok Kedua, yang terdiri dari partai-partai nasionalis dan Kristen, membentuk Partai Demokrasi Indonesia (PDI). Dengan adanya fusi ini partai-partai politik yang ada menjadi tiga, yaitu, PPP, PDI, dan Golkar. ${ }^{32}$

Orde Baru, jauh lebih sukses dibandingkan Soekarno dalam hal memperlemah partai politik melalui deparpolisasi, massa mengambang (floating mass), dan memberlakukan azas tunggal Pancasila sebagai satu-satunya asas bagi semua partai politik (termasuk juga Organisasi Massa); tentu saja pemberlakuan azas tunggal itu memengaruhi eksistensi PPP sebagai partai berbasis Islam. Sementara itu, upaya Deparpolisasi dengan cara bahwa partai politik yang diistilahkan oleh Orde Baru adalah partaipartai politik selain Golkar. Golkar dianggap bukan partai politik. Deparpolisasi bertujuan untuk mengurangi pengaruh partai politik di dalam masyarakat dengan merusak citra partai politik di mata masyarakat, mempersulit warga masyarakat untuk menjadi anggota partai politik, dan mengucilkan serta tidak melayani masyarakat yang menjadi anggota atau bersimpati kepada partai politik. Secara lambat-laun, namun pasti, di dalam masyarakat terbentuk sikap antipati terhadap partai politik dan citra buruk tentang partai politik.

Kebijakan massa mengambang yang diterapkan oleh Orde Baru adalah kebijakan yang mengharuskan warga masyarakat di daerah pedesaan tidak bergabung dengan partai politik, hal mana gerak partai politik non-Golkar hanya sampai tingkat kecamatan, sementara Golkar yang diidentifikasi sebagai non-partai terlepas dari dampak itu. Meski begitu terjadi pengupayaan sistimatis yang 32 Romli, Mencari Format Sistem Kepartaian Masa Depan, 21

Efriza: Eksistensi Partai Politik Dalam Persepsi Publik 
dilakukan oleh aparat birokrasi untuk mengucilkan PPP dan PDI. Massa pemilih di pedesaan diusahakan dengan segala cara untuk tidak menjadi bagian dari partai politik dengan mencegah mereka untuk dipengaruhi oleh partai politik. Situasi ini memberi peluang bagi Golkar untuk menggarap massa pemilih di pedesaan karena Golkar hadir melalui Camat, Kepala Desa, dan perangkat desa lainnya. Massa 32 tahun kekuasaan Orde Baru telah menghasilkan budaya politik anti partai politik atau curiga terhadap partai politik yang kuat di dalam masyarakat. Orde Baru telah meninggalkan warisan menghambat perkembangan partai politik di Indonesia. ${ }^{33}$

Memasuki era reformasi, terjadi perubahan dengan adanya kebebasan mendirikan partai politik, dan pilihan menerapkan sistem multipartai merupakan sesuatu yang jamak (natural) di dalam masyarakat Indonesia, meski sistem kepartaian yang memperoleh dukungan riil dari para pemilih pada dasarnya lebih mengarah kepada sistem yang bercorak multipartai moderat, jika dilihat dari segi jumlah. Argumen demikian didasari oleh fakta hasil lima kali pemilu secara demokratis yang pernah dilakukan, yaitu Pemilu 1955, Pemilu 1999, Pemilu 2004, Pemilu 2009, dan Pemilu 2014. Lima kali pemilu ini menghasilkan partai-partai yang memperoleh dukungan cukup berarti pada kisaran empat sampai sepuluh partai saja. Partai-partai lainnya hanya memperoleh dukungan sangat kecil. ${ }^{34}$ Jadi, pasca reformasi pertumbuhan dan peran partai politik kian membesar dibandingkan dengan dua era sebelumnya yakni Orde Lama dan Orde Baru.

\section{Partai Politik di Era Reformasi}

Setelah mengalami pengkerdilan peran partai pada masa Orde Baru, partai politik kembali bergeliat pada era reformasi yang membawa

33 Rauf, "Partai Politik dan Sistem Kepartaian," 9-10

34 Kacung Marijan, Sistem Politik Indonesia Konsolidasi Demokrasi Pasca Orde Baru (Jakarta: Kencana, 2010), 66 angin segar. Runtuhnya pemerintahan Soeharto mengubah tatanan politik di Indonesia, termasuk di dalamnya sistem kepartaian. Jika pada masa Orde Baru Indonesia dikuasai oleh pemerintahan yang otoritarian dengan sistem partai tunggalnya, maka pada era reformasi demokrasi langsunglah yang berkuasa. Akhirnya, setiap individu di Indonesia memiliki hak yang sama untuk mengeluarkan pendapat, berserikat dan berekspresi. Euforia politik ditandai dengan kemunculan begitu banyak partai politik.

Kemunculan banyak partai politik pada era Reformasi ini ditandai dengan dikeluarkannya kebijakan pemerintahan interregnum B.J. Habibie untuk menerapkan kembali sistem multipartai. Dengan kebijakan ini, euforia politik, demokrasi dan kebebasan juga menghasilkan penghapusan kewajiban partai politik untuk menjadi Pancasila sebagai satusatunya asas, seperti ditetapkan pada UndangUndang Keormasan tahun 1985.

Masyarakat secara beramai-ramai mempersiapkan partai politik untuk ikut serta dalam pesta demokrasi atau pemilu yang akan berlangsung pada tahun 1999. Jika pada masa Orde Baru hanya terdapat dua partai dan satu golongan karya, pada tahun 1999 tercatat ada 141 partai politik dan 48 di antaranya dinyatakan memenuhi syarat untuk dapat mengikuti Pemilu Anggota Dewan Perwakilan Rakyat (DPR), Dewan Perwakilan Rakyat Daerah I (DPRD I), dan Dewan Perwakilan Rakyat Daerah II (DPRD II) yang jatuh pada bulan Juni 1999. Banyaknya partai politik pada masa ini membuat Indonesia secara mutlak menganut sistem kepartaian multipartai. ${ }^{35}$

Setelah tahun 1999, partai politik menjadi tulang punggung bagi berjalannya demokrasi di Indonesia. Partai tidak lagi hanya sebagai boneka dan perpanjangan tangan bagi penguasa seperti di masa Orde Baru, tetapi partai pemegang peranan penting

35 Muhadam Labolo dan Teguh Ilham, Partai Politik dan Sistem Pemilihan Umum di Indonesia: Teori, Konsep dan Isu Strategis, (Jakarta: RajaGrafindo Persada, 2015), 99-100 
hampir di semua lini kehidupan politik. Partai menjadi kendaraan politik satu-satunya dalam Pemilihan Umum Legislatif (Pileg) dan Pemilihan Presiden (Pilpres), serta menjadi pengusung calon kepala daerah dalam pemilihan kepala daerah (Pilkada). Tidak hanya kendaraan politik, partai politik seperti telah dijelaskan di atas bahwa memiliki banyak fungsi lain, yakni untuk komunikasi politik, pendidikan politik, dan pengatur konflik. ${ }^{36}$

Selama 21 tahun Reformasi yang telah kita lalui, setelah runtuhnya pemerintahan Orde Baru, pendirian partai politik masih tumbuh subur bak jamur di musim hujan. Meski terjadi fluktuasi partai-partai politik sebagai partai politik peserta pemilu, seperti, partaipartai politik yang memasuki arena Pemilu 2004 lebih sedikit kalau dibandingkan dengan Pemilu 1999, tetapi Pemilu 2009 lebih banyak jika dibandingkan Pemilu 2004, sedangkan Pemilu 2014 lebih sedikit kalau dibandingkan dengan Pemilu 2019 mendatang.

Rinciannya adalah Pemilu 2004 diikuti oleh 24 partai politik peserta pemilu, lebih sedikit dibandingkan dengan Pemilu 1999 yang terdiri dari 48 partai politik sebagai peserta pemilu. Pemilu 2009 mengalami kenaikan drastis bahwa jumlah partai yang menjadi peserta pemilu di tingkat nasional sebanyak 38 partai dan 6 partai lokal di Aceh, tetapi mengalami penurunan pada Pemilu 2014 lalu bahwa jumlah partai yang lolos sebagai peserta pemilu hanya 12 partai nasional dan 3 partai lokal. Sekarang ini, menuju Pemilu 2019 jumlah partai yang lolos sebagai peserta pemilu adalah 16 partai nasional dan 4 partai lokal.

Melihat realitasnya, dalam pemilu-pemilu yang telah berlangsung bahwa partai-partai baru akan terus berdatangan dan dapat memasuki arena pemilu, ini tak lepas dari belum terlembaganya proses penyelesaian

36 Aisyah Putri Budiarti, Personalisasi Partai Politik di Indonesia Era Reformasi (Jakarta: Yayasan Obor Indonesia, 2018), xiii konflik internal di dalam partai. Dalam banyak kasus, partai-partai baru itu tidak didirikan oleh para elite politik baru, melainkan oleh para elite politik lama, hingga sekarang ini memasuki Pemilu 2019. Ketika mereka kecewa dan tersingkir di dalam arena konflik, khususnya dalam perebutan kepemimpinan partai, mereka berusaha membentuk partaipartai baru. Partai-partai baru itu dibaratkan seperti 'old wine in new bottle'. ${ }^{37}$ Misalnya, partaipartai yang berasal dari partai Golkar, yang baru-baru ini hadir seperti: Hanura, Gerindra, Nasdem, dan Partai Berkarya merupakan sempalan partai Golkar.

Melihat realitas di atas, dan ditambah fakta setelah pemilu sebelumnya yang menunjukkan bahwa partai-partai baru dapat memperoleh kursi di lembaga DPR, maka memasuki Pemilu 2009, tampak bahwa partaipartai di Indonesia perlahan tetapi pasti secara drastis mengurangi muatan ideologis mereka dalam rangka untuk meraih sebanyak mungkin jumlah pemilih. Partai-partai politik cenderung memilih menjadi catch all party. Tampaknya pembentukan dan pemeliharaan konstituen tak lagi menjadi agenda kerja partai. Begitu pula dalam menjalankan fungsi partai, tampak sebagian baru akan terlihat gregetnya saat tibanya pemilu. Merawat konstituen dengan berbasis program jangka panjang tidak menjadi prioritas. Karena kebutuhan politik jangka pendek berupa mendulang suara, lebih mendesak, sehingga partai lebih menempuh langkah-langkah instan, tak terkecuali sikap tak acuh partai untuk membuat pola rekrutmen internal partai yang bagus, malah perilaku partai politik itu sendiri yang lebih memilih menempuh jalan pintas dengan melakukan rekrutmen anggota yang dilakukan secara transaksional dan tertutup. ${ }^{38}$

37 Kacung Marijan, Sistem Politik Indonesia: Konsolidasi Demokrasi Pasca-Orde Baru, 66

38 Syaifullah Ma'shum, DPR Terhormat DPR Dihujat: Refleksi Lima Tahun di DPR Periode 2004-2009 (Catatan Sejarah Sang Wakil Rakyat), (Jakarta: Kreasi Cendekia Pustaka, 2012), 3

Efriza: Eksistensi Partai Politik Dalam Persepsi Publik 
Akibat dari perilaku politisi dan partai politik dalam rangkaian pileg, pilpres, dan pilkada - justru mengkonfirmasikan terbangunnya watak "partai mengambang" (floating party), perwujudan partai politik tumbuh dengan kaki lemah atau malah tak berkaki di masyarakat. ${ }^{39}$

Harus dipahami bahwa, perubahan organisasi partai politik itu merefleksikan perubahan dalam masyarakat dan politik. Ketika partai politik lebih menekankan pemenangan pemilu, dengan mengurangi arti penting keanggotaan partai. Memang catch all party dapat memenangkan pemilihan dengan berupaya merebut sebanyak mungkin kalangan pemilih. Tetapi pada saat yang sama, para pemilih tampaknya kurang mengenali jati diri partai politik akibatnya pemilih mengubah pilihannya dari satu pemilu ke pemilu lain, sikap ini pada akhirnya dianggap suatu kewajaran, meski sebenarnya seperti diungkapan di atas bahwa ini menunjukkan perwujudan partai politik dengan kaki lemah atau malah tak berkaki di masyarakat. ${ }^{40}$

Jika di masa Orde Baru, kita berhadapan dengan gejala "massa mengambang" (floating mass), masyarakat pemilih yang berkaki lemah atau malah tidak berkaki. Karena gerak partai politik dibatasi hingga tak bisa menjangkau basis pemerintahan terendah (di tingkat desa), tempat para pemilih sejatinya beraktivitas, masyarakat dipaksa untuk tidak beraktivitas di dalam dan berasosiasi dengan partai politik. Dalam "pemilu," mereka menjadi massa mengambang yang diperebutkan. Lalu, Golkarlah yang merengguk keuntungan karena tak menyebut dirinya partai politik sehingga memiliki ruang gerak leluasa untuk menggalang calon pemilih.

Bagi Pemerintahan Orde Baru, partai politik telah menjadi sumber penyebab instabilitas politik dan kegagalan ekonomi

39 Eep Saefulloh Fatah, "Gejala Partai Mengambang," Kompas, 18 November 2006, 42

40 Alexandra Cole, Perbandingan Partai Politik, di Ilmu Politik Dalam Paradigma Abad Ke-21 (Jilid 1), ed. John T. Ishiyama dan Marijke Breuning, 254 sepanjang sejarah Indonesia merdeka. Sikap politik pemerintahan Orde Baru menginginkan adanya sistem kepartaian yang ramping dengan jumlah partai yang terbatas; dan terjaminnya hubungan legitimasi di antara masyarakat dengan pemerintahan. Maka, pembatasan peran partai politik dan hegemonisasi Golkar menjadi pilihan pemerintahan Orde Baru. ${ }^{41}$

Masa itu telah lama berlalu dan menjadi sejarah hitam politik semata. Demokratisasi semestinya menguatkan kembali kaki masyarakat dan mendorong kompetisi antarpartai di atas lahan baru yang serba terbuka. Celakanya, yang kemudian tumbuh dari lahan baru ini adalah "partai mengambang”, bahkan efektivitas partai politik cenderung tidak bertanggungjawab dan tidak tanggap terhadap konstituennya, setidaknya menurut Eep Saefulloh ${ }^{42}$ bahwa empat perilaku buruk partai politik secara institusi tampak mudah dicermati, yakni nir-ideologi, nir-identitas, tipe personalistik dan cenderung oligarkis, dan nir-konstituen; untuk memahaminya sebagai berikut.

Pertama, nir-ideologi. Partai mengambang tidak punya ideologi kecuali pragmatisme. Sepanjang masa Orde Baru, ideologi memang diberangus. Sepeninggal Soeharto, ideologiideologi tidak serta-merta bertumbuhan. Faktanya, hanya pragmatisme yang ternyata tersisa dari setiap puing ideologi lama. Pembumihangusan ideologi menyisakan pragmatisme sebagai kerak, abu atau ampasnya.

Bendera-bendera ideologi atau aliran memang dikibarkan, tetapi sejatinya hanya menggarisbawahi keseragaman pemihakan pada pragmatisme itu. Umumnya partai era reformasi pun nyaris seragam, bahkan partaipartai memilih untuk berusaha seragam, gejala ini mulai terlihat sejak Pemilu 2009 lalu, bahwa partai-partai berbasis agama misalnya: Partai Keadilan Sejahtera (PKS), Partai Damai

41 Fatah, Pengkhianatan Demokrasi ala Orde Baru, 194

42 Fatah, "Gejala Partai Mengambang," 42 
Sejahtera (PDS), dan Partai Amanat Nasional (PAN); dengan kesadaran diri mendeklarasikan menjadi partai terbuka untuk rumah berbagai golongan yang ada di masyarakat. PKS yang awalnya mempunyai basis dari kalangan Islam yang akhirnya menyatakan gagasan untuk menjadi partai terbuka atau "PKS untuk semua" dengan alasan bahwa PKS adalah partai yang menjunjung tinggi pluralitas. Begitu juga dengan Partai Demokrat yang mengklaim dirinya sebagai partai untuk semua. Hal tersebut terjadi karena partai-partai politik itu lebih mengikuti logika elektoral dengan menjadi partai yang mengincar segmen pemilih yang lebih luas (catch all party), agar ceruk pasar pemilih mereka nantinya secara statistik dapat lebih besar, dibandingkan masih tetap merepresentasikan basis sosial partai berdasarkan semangat pendirian partai diawal. Partai-partai itu akhirnya mengambang karena tak berkaki di tengah kemajemukan masyarakat kita.

Kedua, nir-identitas. Partai-partai kita di era reformasi ini, nyaris tanpa kecuali, tak punya ketegasan orientasi politik dan program. Sesungguhnya, ini terjadi sejak tahun 1999 hingga sekarang. Semua partai politik, berusaha mengurusi semua hal, menjangkau semua dimensi persoalan. Mereka tak tertarik untuk mempertajam orientasi politik dan programnya ke sektor persoalan, atau isu spesifik yang hidup di tengah masyarakat. Konsekuensinya, secara fisik kita punya banyak partai, tetapi sulit membedakan identitas politik yang satu dengan yang lain. Nyaris semua partai yang nir-identitas ini pun gagal mewakili keragaman aspirasi masyarakat pemilih. Mereka mengambang karena menyikapi berbagai isu tanpa platfrom.

Ketiga, tipe personalistik dan cenderung oligarkis. Tipe kepartaian di Indonesia saat ini (bahkan menuju pemilu 2019) hanya terbagi menjadi dua, yakni tipe programmatik dan tipe personalistik. Tipe programmatik yang menitikberatkan pada aktivitas program- program yang dibawa oleh kandidatnya seperti: Partai Golkar, PKS, dan PSI. Sedangkan tipe personalistik yakni partai yang bertumpu pada patronase yang kuat dengan adanya pemimpin yang dianggap kharismatik, seperti: PDI Perjuangan, PAN, PKB, Gerindra, Hanura, Partai Demokrat, Partai Nasdem, Partai Berkarya, PPP, Partai Garuda, PKPI, Partai Perindo, dan Partai Bulan Bintang. Meski begitu, umumnya partai politik bertahan pada karakter kepemimpinan dan organisasi yang oligarkis. Pusat kekuasaan tumbuh di sekitar sedikit elite utama di pucuk organisasi partai, sehingga sulit untuk diterapkannya sistem otonomi kepartaian. Kepentingan dan kenikmatan partai pun tak terdistribusikan ke luar lingkaran elite utama itu. Akhirnya, operasi partai terkendali di tangan segelintir pihak, ini sebuah realitas dari oligarkis partai. Bahkan, tentu saja aspirasi populis dari akar rumput, kerap sulit dikonversi menjadi kebijakan partai, ini menunjukkan bahwa secara normatif partai politik memang wadah berkiprahnya setiap kader, namun secara riil politik, partai politik adalah dunia kaum elite dengan watak otokratik.

Dalam nuansa ini maka tidak heran kalau kemudian berbagai peristiwa politik - di lingkungan partai maupun di luar partai, apakah yang berupa konflik maupun konsensus dan acara-acara hajatan besar yang diselenggarakan partai politik - lebih ditentukan oleh kekuatan eksklusif dari balik layar yang berasal dari aspirasi para elite. Bahkan, pelibatan massa dan kader sejatinya hanyalah bersifat semu. Tak lebih dari sekadar penggembiara dan pemberi legitimasi atas kehendak para elite itu.

Keempat, yang utama, nir-konstituen. Secara umum, partai-partai era reformasi masih dicirikan oleh kemiskinan kemauan dan kemampuan profesional mereka dalam membentuk serta memelihara konstituen. Sebagian besar partai mendekati masyarakat 
manakala mereka membutuhkan suara dukungan dalam pemilu. Partai politik mendekat manakala membutuhkan pemilih dan serta-merta menjauh lalu lenyap segera setelah kebutuhannya sukses (atau gagal) terpenuhi.

Reformasi sebetulnya memberi peluang bagi partai politik untuk melakukan penggalangan dan pemeliharaan konstituen. Tetapi realitasnya, contoh kecil saja, konstituen yang merupakan anggota partai, malah karakter keanggotaannya menggantung ke atas. Artinya, di dalam internal partai, anggota lebih banyak ditentukan dari atas. Akibatnya, dukungan konstituen terhadap partai politik setiap saat dapat berubah tergantung kepentingan sesaat konstituen, isu aktual yang berkembang di publik dan pemahaman konstituen terhadap situasi aktual partai. ${ }^{43}$

Celakanya, di tengah ruang manuver yang leluasa, partai masih menggunakan cara berpikir lama: berlibur manakala tak ada pemilu dan menjadi sibuk bukan kepalang kerap pemilu mendekat. Hubungan partai dengan pemilu pun bersifat ad hoc, sementara, dan bubar selepas pemilu, ini menunjukkan bahwa substansi pemilu hanya terjadi dalam hitungan delapan jam (07.00-15.00), setelah kelar quick count, lepaslah hubungan rakyat dengan partai politik dan wakil yang diharapkan mewakilinya.

Konsekuensinya, hubungan dengan dukungan konstituen yang akhirnya bersifat labil, situasi ini berpengaruh terhadap perkembangan partai politik, hal mana arah perkembangannya lebih banyak dipengaruhi dari faktor eksternal, seperti: media massa yang menguasai opini publik dan upaya politik transaksional (money politics) yang dianggap dapat memenuhi tuntutan dan kebutuhan pragmatisme pemilih. Sedangkan, ideologi, program, kompetensi dan manajemen partai belum banyak berpengaruh terhadap arah kebijakan dan perkembangan partai. ${ }^{44}$

43 Fatah, "Gejala Partai Mengambang," 42-43; dan Noor, Quo Vadis Demokrasi Kita?, 23

44 Warsito Ellwin, dan Hari Subagyo, Konstituen Pilar
Jadi, pada era reformasi ini, partai politik seolah terlepas dari semua belenggu yang mengekang selama ini. Rezim Orde Lama dan Orde Baru yang otoriter kemudian berganti kepada rezim reformasiyangdemokratis. Melalui kebijakan kembali kepada sistem multipartai, dan partai-partai politik juga diperkenankan untuk tidak harus menjadikan Pancasila sebagai ideologi partai. Antusias masyarakat dalam berpolitik untuk membentuk partai politik masih cukup tinggi dengan munculnya partaipartai politik baru, sebut saja Pemilu 2019 yang merupakan pemilu kelima di era reformasi ini empat partai baru berhasil turut serta sebagai peserta pemilu yakni Perindo, PSI, Partai Berkarya dan Partai Garuda. Namun, kondisi partai politik pada masa ini tetap meninggalkan banyak catatan seperti dijelaskan di atas, salah satunya adalah masalah deideologi partai. Keasyikan partai politik untuk menghadapi pemilu membuat partai menjadi pragmatis dan secara perlahan berubah menjadi partai catch all dengan berusaha merangkul semua basis pemilu. $^{45}$

\section{Persepsi Publik terhadap Eksistensi Partai Politik dan Kinerja DPR}

Sangat disayangkan di orde reformasi ini jumlah partai politik boleh bertambah, tetapi tidak menunjukkan bahwa adanya korelasi kebebasan berpolitik ini dengan proses penyerapan aspirasi dan kepentingan masyarakat bahkan konstituennya. Malah kita terjebak pada kebangkitan partycracy, yang menurut Indra J. Piliang bahwa diibaratkan seperti buah busuk yang dipetik dari tanah kering dan hama, akibat syahwat kekuasaan dan kemiskinan kesadaran dalam pengorganisasian kepartaian. ${ }^{46}$

Titik awal terjadinya kemerosotan demokrasi adalah sesaat setelah disetujuinya Utama Partai Politik (Jakarta: Friedrich Naumann Stiftung, 2011), xvii

45 Muhadam Labolo dan Teguh Ilham, Partai Politik dan Sistem Pemilihan Umum di Indonesia, 105

46 Pilliang, "Kebangkitan "Partycracy"”, 4 
rumusan kedaulatan rakyat yang ada di tangan rakyat tetapi dilaksanakan berdasarkan undang-undang dasar. Maksud dari rumusan hasil amandemen UUD 1945 bahwa telah ditinggalkannya rumusan dasar supremasi parlemen menjadi supremasi konstitusi. Sayangnya, sejak itu, demokrasi yang semestinya bertumpu pada apa maunya rakyat bergeser menjadi apa maunya partai politik. Pembentukan lembaga-lembaga negara sangat ditentukan oleh apa maunya partai melalui fraksi-fraksi di DPR, sebut saja misalnya, seleksi untuk anggota Komisi Yudisial (KY), Komisi Pemberantasan Korupsi (KPK), dan Komisi Pemilihan Umum (KPU). Penentu akhirnya adalah apa maunya DPR - dalam hal ini partai politik yang ada di dalamnya. Kedaulatan rakyat pun menjadi kedaulatan partai. ${ }^{47}$

Situasi sekarang ini kita bisa mengatakan bahwa negara sedang berada dalam masa demokrasi yang defisit (deficit democracy). Defisit demokrasi ini tumbuh sejak kepercayaan publik terhadap politisi maupun institusi politik menurun, banyak partai dan wakil rakyat (representative in democracy system) yang kehilangan hubungan dengan yang diwakili (represent). Harapan masyarakat di masa-masa awal runtuhnya Orde Baru, yakni agar partai politik yang ada mampu membebaskan diri dari kebiri Orde Baru dan menjadi demokrasi yang mewakili kepentingan konstituen, tampaknya tinggal angan-angan.

Bagi suatu negara yang menganut prinsip keterbukaan dan berdemokrasi, untuk menyikapi kinerja partai politik maupun pemerintah dalam mengelola kekuasaan, biasanya pendapat umum sangat diperhatikan sebagai kekuatan kelima dari demokrasi (selain lembaga trias politika dan pers), dan tentunya juga diperhatikan oleh lembaga-lembaga negara. Namun, di era reformasi peran partai politik dalam persepsi masyarakat, bahwa skeptisme masyarakat yang terjadi, ini ditemukan dalam

47 Sulardi, "Kemunduran Demokrasi," Koran Tempo, 24 Mei 2017, 11 jajak pendapat yang dilakukan oleh Skala Survei Indonesia (SSI) pada 2012 lalu. Survei itu menunjukkan bahwa ketidakpuasan masyarakat lebih besar 52,6 persen terhadap kinerja partai politik selama ini dibandingkan dengan tingkat kepuasan yang lebih sedikit sebesar 30,0 persen. Ketidakpuasan masyarakat terhadap kinerja partai tentu linear dengan ketidakpercayaan masyarakat bahwa partai politik memperjuangkan kepentingan rakyat yaitu 51,4 persen, sedangkan yang mempercayai jumlahnya lebih sedikit sebanyak 32,3 persen. ${ }^{48}$ Celakanya, tingkat kepercayaan masyarakat terhadap partai politik malah semakin buruk. Hasil Survei Indobarometer mengkonfirmasi bahwa masifnya ketidakpercayaan masyarakat terhadap partai politik juga berdampak terhadap tingkat kedekatan masyarakat kepada partai politik. Sebanyak 62,9 persen masyarakat merasa tidak dekat dengan partai. ${ }^{49}$ Untuk lebih mendalami materi mengenai Survei Kepercayaan Masyarakat terhadap lembaga negara utamanya Partai Politik dapat dilihat dalam Tabel 1.

Apa yang menyebabkan masalah utama partai politik bagi masyarakat? Sehingga persepsi negatif diberikan publik terhadap partai politik, menurut Survei Political Communication (Polcomm) Institute yang di rilis 2014, bahwa krisis kepercayaan rakyat atas partai politik setidaknya dipicu oleh tiga hal: pertama, banyaknya kader partai politik terjerat kasus korupsi; kedua, konflik internal partai politik; dan ketiga, sejumlah pelanggaran etika yang dilakukan kader partai politik. Krisis kepercayaan rakyat pada partai politik ini dinilai memicu kekuatan rakyat (people power) dalam bentuk relawan politik non-partai pada Pilpres 2014 lalu. ${ }^{50}$ Selain ketiga hal di atas,

48 Skala Survei Indonesia, "Hasil Nasional tentang Kinerja Partai Politik dan Anggota Legislatif", Oktober 2012.

49 Ahmad Faiz, "Survei: Partai Politik Tak Dipercaya Publik," Koran Tempo, 23 Maret 2017, 7

50 Rully Chairul Azwar, "Partai Politik Di Tengah Ancaman "Virus" Oligarki dan Politik Kartel," Jurnal Ketatanegaraan, no. 5 (November 2017), 3

Efriza: Eksistensi Partai Politik Dalam Persepsi Publik 
Tabel 1. Kepercayaan Masyarakat Terhadap Partai Politik

\begin{tabular}{lccc}
\hline \multirow{2}{*}{ Lembaga Survei } & \multicolumn{3}{c}{ Kepercayaan Masyarakat } \\
\cline { 2 - 4 } & Kepercayaan & Ketidakpercayaan & $\begin{array}{c}\text { Tidak Tahu/Tidak } \\
\text { Menjawab }\end{array}$ \\
\hline $\begin{array}{l}\text { Skala Survei Indonesia } \\
\text { (2012) }\end{array}$ & $32,3 \%$ & $51,4 \%$ & $16,3 \%$ \\
$\begin{array}{l}\text { Indikator Politik } \\
\text { Indonesia (2013) }\end{array}$ & $31 \%$ & $58 \%$ & $11 \%$ \\
Indobarometer (2017) & $35,3 \%$ & $48,8 \%$ & $15,9 \%$ \\
\hline
\end{tabular}

Sumber: Diolah dari berbagai sumber.

masalah utama partai politik bagi masyarakat berdasarkan hasil Survei Centre for Strategic International Studies (CSIS) pada 2017 yakni: pertama, lemahnya kepercayaan masyarakat terhadap partai politik sebesar 44,2 persen; kedua, kepemimpinan partai yang bermasalah, sebesar 21,2 persen; ketiga, jenjang kader yang tidak terencana dengan baik, sebesar 11,1 persen; keempat, demokrasi internal partai yang tidak berjalan dengan baik, sebesar 9,8 persen; dan kelima, menguatnya politik dinasti di sejumlah partai, sebesar 7,2 persen..$^{51}$

Efek dari ketidakpercayaan masyarakat sekaligus ketidakdekatan masyarakat dengan partai politik, tentu saja berdampak pula terhadap tidak percayanya masyarakat pada lembaga DPR. Hasil Survei SSI menjelaskan realitas bahwa masyarakat menganggap anggota legislatif tidak mampu dalam melakukan tugasnya, yaitu sebesar 45,3 persen, sedangkan yang menyatakan mampu sebesar 34,0 persen. Ketidakpercayaan masyarakat tentu diikuti ketidakyakinan masyarakat bahwa anggota legislatif memperjuangkan kepentingan rakyatnya yakni sebesar 52,1 persen, sementara yang menyatakan peduli sebesar 28,5 persen. ${ }^{52}$

51 Laporan Survei di presentasikan pada 12 September 2017, yang dilakukan oleh Centre for Strategic and International Studies (CSIS), diakses 20 April 2019, https://www.csis.or.id/uploaded_file/event/ pemaparan_hasil_survei_opini_publik_tiga_tahun_ pemerintahan_joko_widodo___jusuf_kalla__kinerja_ pemerintahan_dan_peta_politik_nasional__notulen. pdf

52 Skala Survei Indonesia, "Hasil Nasional tentang Kinerja Partai Politik dan Anggota Legislatif”, Oktober 2012.
Mengkonfirmasi pembaruan hasil survei juga bisa kita pahami dari survei Indikator Politik Indonesia yang dirilis Agustus 2016 lalu, bahwa mayoritas publik yang mempercayai lembaga DPR hanya 53 persen, sedangkan 40 persen tidak percaya. Hasil survei ini juga turut menjelaskan bahwa dari sisi kepercayaan terhadap DPR dan Partai Politik adalah paling buruk dibandingkan dengan Presiden, Tentara Nasional Indonesia(TNI), dan KPKyang masingmasing berada di tiga besar paling dipercaya masyarakat. Bahkan, menurut Burhanuddin Muhtadi, bahwa tingkat kepercayaan terhadap partai politik dan DPR tidak pernah naik kelas sejak 2002 lalu..$^{53}$

Seiring perjalanan waktu masyarakat nampaknya semakin merasakan jurang yang semakin lebar antara "agenda masyarakat" dan "agenda partai politik", pilihan sikap pragmatisme partai politik serta didukung juga oleh perilaku politik politisi, akhirnya membuat persepsi masyarakat umum, menurut Firman Noor bahwa, masyarakat melihat kerja-kerja politik sekadar sebagai soal pragmatis yang kering ala pedagang untuk berkuasa itulah yang telah secara efektif menyudutkan dan mengaburkan makna luhur kerja-kerja politik, termasuk meredupkan citra kaum politisi di dalamnya. ${ }^{54}$

Hingga sekarang ini, dapat dikatakan bahwa ternyata kinerja DPR juga belum 53 Faiz, "Survei: DPR dan Partai Tidak Dipercaya Publik," 9

54 Noor, Quo Vadis Demokrasi Kita?, 4 
menunjukkan sesuai harapan publik yang diwakili. Penilaian ini terlihat dari integritas mereka menyuarakan aspirasi rakyat lewat kinerjanya. Mayoritas publik berdasarkan jajak pendapat "Kompas" tahun 2017 menyatakan bahwa, masyarakat masih menganggap tidak memuaskannya hasil kerja DPR sehingga buruk pula Citra DPR saat ini dengan prosentase sebesar 71,3 persen. Misalnya, terhadap kinerja legislasi, tampak bahwa 75,4 persen tidak puas dengan DPR, sementara perannya dalam mengontrol dan mengawasi kinerja pemerintah bahwa ketidakpuasan masyarakat sebesar 66,9 persen, dan dalam memperjuangkan kepentingan rakyat ketidakpuasan masyarakat sebesar 74,9 persen. ${ }^{55}$ Bahkan, dalam relasi antara DPR dan Konstituennya, menurut hasil Survei Centre for Strategic and International Studies (CSIS) pada 2017, bahwa masyarakat tidak pernah mengikuti kegiatan reses DPR (95,2 persen), masyarakat merasa tidak pernah berkomunikasi dengan DPR (95,6 persen), dan menyampaikan pendapat secara langsung ke anggota DPR (94,6 persen). ${ }^{56}$

Perkembangan defisit demokrasi di Indonesia saat ini, malah dapat dikatakan sedang mengalami problematika kronis karena dua prasyarat demokrasi mengalami kemunduran. Jika sebelumnya DPR kembali menjadi sorotan berdasarkan hasil survei Transparency International Indonesia (TII) yang menyatakan DPR pada 2017 masih menjadi lembaga pemerintahan yang paling tinggi tingkat korupsinya dengan angka 54 persen, setelah terungkapnya kasus korupsi pengadaan Kartu Tanda Penduduk elektronik

55 Susanti Agustina S., Toto Suryaningtyas, dan Litbang Kompas, "Jajak Pendapat "Kompas" Mencari Penanda Wakil Rakyat”, Kompas, 31 Juli 2017, 5

56 Laporan Survei di presentasikan pada 12 September 2017, yang dilakukan oleh Centre for Strategic and International Studies (CSIS), diakses 20 April 2019, https:// www.csis.or.id/uploaded_file/event/pemaparan_hasil_ survei_opini_publik_tiga_tahun_pemerintahan_joko_widodo___jusuf_kalla_kinerja_pemerintahan_dan_ peta_politik_nasional__notulen.pdf
(KTP-el) yang diduga menyeret sebagian besar anggota DPR periode 2009-2014 dan pejabat negara lainnya. Kasus tersebut mengakibatkan kerugian negara $\operatorname{Rp} 2,3$ triliun dari nilai proyek Rp 5,9 triliun. Survei ini juga semakin menegaskan jika lembaga DPR di era reformasi ini belum mengalami perubahan persepsi sebagai institusi terkorup di negeri ini, bahkan penelitian TII tersebut semakin meningkatkan citra buruk DPR seperti sesuai dengan surveinya di tahun 2013 dan 2005 lalu yang menempatkan DPR sebagai institusi terkorup kedua di negeri ini. ${ }^{57}$

Problematika korupsi juga masih terus menerus terjadi berulang-ulang dalam proses pencalonan Pilkada, meski berbau oligarkis. Tetapi realitas bahwa tak mungkinnya rekomendasi calon kepala daerah secara cumacuma, dengan idiom melekat khas penentuan calon kepala daerah bahwa "tidak ada makan siang yang gratis”, berdampak pada Pilkada serentak 2018 ini disinyalir oleh KPK bahwa 90 persen kepala daerah peserta Pilkada 2018 terindikasi terlibat kasus korupsi bahkan ada yang berstatus petahana. ${ }^{58}$

Menjelang Pemilu 2019 ini diprediksi bahwa citra partai politik semakin merosot tajam di mata masyarakat, sebab sekitar 34 hari menuju Pemilu 2019 dalam gelaran Operasi Tangkap Tangan (OTT), tim Satgas KPK menangkap Ketua Umum PPP, Romahurmuziy, di Jawa Timur. Dalam periode reformasi ini menunjukkan bahwa selain Romahurmuziy, sebelumnya KPK sudah menjerat empat ketua umum partai politik yakni: Presiden PKS, Luthfi Hasan Ishaaq; Ketua Umum Partai Demokrat,

57 Umar Mukhtar dan Hazliansyah, "Survei TII: DPR Lembaga Terkorup," Republika, 08 Maret 2017, diakses 26 Februari 2019, http://nasional.republika.co.id/ berita/nasional/umum/17/03/08/omgr7y280-surveitii-dpr-lembaga-terkorup

58 Widya Lisfianti dan Dani Dahwilani, "90 Persen Pilkada Berpotensi Jadi Tersangka,” iNews, 07 Maret 2018, diakses 25 Februari 2019, http://www.inews. $\mathrm{id} /$ multimedia/read/90-persen-peserta-pilkadaberpotensi-jadi-tersangka?sub_slug=video

Efriza: Eksistensi Partai Politik Dalam Persepsi Publik 
Anas Urbaningrum; Ketua Umum PPP, Suryadharma Ali; dan Ketua Umum Partai Golkar, Setya Novanto; hal mana semuanya sudah divonis dan dijebloskan ke penjara. ${ }^{59}$

Realitas harus diakui bahwa, persepsi negatif publik terhadap partai politik dan DPR menjelang Pemilu 2019 ini tidak juga membaik. Hasil Survei ahli yang dilakukan LIPI, menunjukkan hal yang sama dengan persepsi publik, bahwa kinerja lembaga demokrasi seperti Partai Politik dan Polri memperoleh penilaian terendah sebagai institusi berkinerja baik, misalnya Partai Politik dan Polri memperoleh peringat posisi buncit dari bawah sebesar 13,10 persen, diikuti oleh lembaga DPR diurutan ketiga dari bawah sebesar 23,45 persen. ${ }^{60}$

Dari sikap partai politik dan politisi dengan citra pencari kekuasaan an sich, salah satu dampaknya adalah semakin enggannya masyarakat untuk mengikuti pemilu hal mana jumlah total masyarakat yang ikut dalam pemilu semakin menurun pada level nasional dan lokal. Misalnya di tingkat nasional, pada Pemilu 1999, tingkat partisipasi pemilih mencapai 90 persen lebih, setelahnya, Pemilu 2004 tingkat partisipasi pemilih merosot menjadi 76 persen, dalam Pemilu 2009 dan 2014 tingkat partisipasi pemilih terjun bebas menjadi 70 persen. Menuju Pemilu 2019 mendatang, ajakan untuk absen memilih mulai marak diungkapkan di sosial media, ancaman akan tingginya keenganan masyarakat memilih tentunya tak bisa dilepaskan karena kekecewaan masyarakat terhadap partai politik dan politisi sehingga dapat membuat tingkat

59 Salman Madira, "Selain Ketum PPP Romi Ini 4 Pemimpin Parpol yang Pernah Ditindak KPK karena Korupsi,"15Maret2019, diakses 15Maret2019, https:// news.okezone.com/read/2019/03/15/337/2030483/ selain-ketum-ppp-romi-ini-4-pemimpin-parpol-yangpernah-ditindak-kpk-karena-korupsi

60 Esty Ekawati, "Pandangan Ahli: Pemetaan Kondisi Politik, Ekonomi, Sosial Budaya, Pertahanan dan Keamanan Menjelang Pemilu Serentak 2019," Makalah disajikan pada pertemuan untuk penyampaian rilis hasil Survei Ahli oleh LIPI, di Hotel JS Luwansa, 7 Agustus 2018 partisipasi pemilih rendah. ${ }^{61}$

Merosotnya citra Partai Politik ini terjadi karena tidak adanya ideologi partai, memang secara formal partai-partai mengusung ideologi tertentu. Tetapi, dalam realitasnya, partai-partai tersebut tidak bisa dibedakan dengan partai-partai yang menyatakan dirinya sebagai partai yang berasas kebangsaan, atau yang mengklaim dirinya sebagai nasionalisreligius. Ideologi partai politik sejak 2009, sudah mengalami distorsi, hal ini terlihat dari ketidakjelasan kaitan ideologi partai dengan sistem filosofi utama masyarakat dan negara, tidak kukuhnya ideologi sebagai landasan program partai, dan lemahnya peran ideologi sebagai pedoman umum dalam menentukan strategi perjuangan partai.

Dalam kondisi ini, ketika kekuatan partai tidak lagi terletak pada ideologi dan program yang dimiliki, maka yang terjadi adalah partaipartai bersandarkan pada kekuatan figur pimpinan partai, patron partai atau bahkan kekuatan uang, wajar korupsi juga tumbuh subur. ${ }^{62}$ Buruknya pelembagaan partai politik merambah luas turut memengaruhi buruknya suprastruktur politik seperti institusi DPR. DPR tersandera oleh kepentingan elite partai atau kepentingan golongannya bukan kepentingan bangsa, seperti ketua umum partai langsung hadir di parlemen memberi arahan, memantau, memberi 'ancaman' kepada para wakil rakyatnya dalam proses pengambilan keputusan sesuai arahan elite itu. Sehingga tidak heran telinga kita sudah umum mendengar wakil rakyat dengan ringan dan tanpa tedeng aling-aling berkata belum ada instruksi partai. Para wakil rakyat tidak bisa bersuara atas nama rakyat secara personal mereka bersembunyi "diketiak" partainya. ${ }^{63}$

61 Rio Apinino, "Membedah Potensi Golput di Pilpres 2019," Tirto.id, 12 Agustus 2018, diakses 14 Maret 2019, https://tirto.id/membedah-potensi-gelombanggolput-di-pilpres-2019,cRYi

62 Lili Romli, Problematik Institusionalisasi Partai Politik di Era Reformasi, (Jakarta: LIPI, 2017), 13-14

63 Efriza, "Reformasi Kepartaian di Indonesia," Radar Sulbar, 21 Oktober 2014, 6 
Dampak dari ketiadaan ideologi partai juga bermuara terhadap identifikasi partai (party identification/Party ID) yang lemah. Menurut Lili Romli $^{64}$ bahwa identifikasi partai merupakan kedekatan psikologis seseorang dengan suatu partai atau loyalitas terhadap suatu partai dan kesetiaan seorang pemilih terhadap partai tertentu. Hubungan psikologis antara pemilih dan partai inilah yang menjadi salah satu kelemahan institusionalisasi partai politik di Indonesia karena sebagian besar pemilih tidak mempunyai hubungan emosional yang kuat dengan partai-partai yang ada.

Ini terlihat dari hasil survei Lembaga Survei Indonesia (LSI) yang menunjukkan bahwa 83 persen lebih pemilih di Indonesia tidak memiliki rasa kedekatan dengan partai. Dari pemilu ke pemilu, perilaku pemilih lebih banyak dipengaruhi oleh faktor-faktor yang bersifat non-ideologis sehingga para pemilih dengan mudah bisa berganti pilihan dalam setiap kali pemilu. Dampak dari hal itu, tidak heran apabila dari pemilu ke pemilu, pemenangnya selalu berbeda-beda. Pada Pemilu 1999 pemenangnya adalah PDIP, Pemilu 2004 Partai Golkar, Pemilu 2009 Partai Demokrat, dan Pemilu 2014 pemenangnya PDIP. Lemahnya identifikasi partai ini juga bisa dilihat dalam pemilihan, seperti Pilpres maupun Pilkada hal mana kandidat yang diusung oleh partai tertentu belum tentu didukung oleh pemilih tersebut. ${ }^{65}$

Kurangnya rasa empati partai politik terhadap persoalan rakyat, tentu melahirkan swing voters (pemilih yang berganti-ganti pilihan politiknya dari satu pemilu ke pemilu berikutnya) juga turut berpotensi memalingkan basis massa ke partai lain. Wajar akhirnya, banyak pemilih di era reformasi ini menentukan pilihannya pada hari pemilu (undecided voters). Jadi, sesungguhnya, selain kemerosotan partisipasi masyarakat dalam

64 Romli, Problematik Institusionalisasi Partai Politik di Era Reformasi, (Jakarta: LIPI, 2017), 14

65 Romli, Problematika Institusionalisasi Partai, 14 memilih juga terjadi hingga sekarang ini bahwa masih banyak pemilih yang belum memiliki kepastian akan pilihannya.

Merosotnya citra partai politik itu, tentu saja akan berakibat buruk terhadap opini publik yang merupakan kekuatan politik penting dalam demokrasi. Opini publik yang buruk niscaya akan membuat citra demokrasi juga merosot, bahkan terjun bebas. Namun kepercayaan publik yang menurun itu, bukan pada demokrasi dalam tataran konsep, melainkan kepercayaan itu merosot terhadap aktor politik atau politisi. Aktor politik atau politisi itu, tentu tidak dapat dipisahkan dengan partai politik yang mengusungnya. ${ }^{66}$ Kemerosotan institusionalisasi partai politik di era reformasi juga ditunjukkan oleh hasil kajian Lili Romli, bahwa institusional partai politik masih lemah di pasca reformasi karena faktor absennya ideologi partai, munculnya kepemimpinan personal/klientelistik, konflik internal partai, dan temuan baru yaitu pragmatisme politik. ${ }^{67}$

Memang harus diakui bahwa berbagai hasil survei telah berkali-kali dirilis dan hasilnya tetap sama hingga sekarang ini, dan hasil ini semestinya dijadikan tantangan bagi DPR dan utamanya partai politik untuk memperbaiki citra diri bahwa lembaga politik dipersepsi publik sebagai hulu semua permasalahan bangsa. Meski demikian, menurut Arifin Anwar bahwa, merosotnya citra partai politik itu, tidak berarti bahwa partai politik itu tidak lagi relevan dalam kehidupan demokrasi sekarang ini. ${ }^{68}$

Dapat dikatakan bahwa pasca reformasi belum memperlihatkan kemajuan malah cenderung mengarah pada defisit demokrasi yang disumbang oleh partai politik, yang berdampak terhadap lembaga DPR. Fakta bahwa perkembangan partai politik sekarang 66 Anwar Arifin, Pencitraan dalam Politik: Strategi Pemenangan Pemilu dalam Perspektif Komunikasi Politik, (Bandung: Pustaka Indonesia, 2006), 202-203

67 Romli, Problematika Institusionalisasi Partai, 21

68 Arifin, Pencitraan dalam Politik, 202-203

Efriza: Eksistensi Partai Politik Dalam Persepsi Publik 
ini kurang responsif terhadap konstituen disebabkan partai-partai di Indonesia perlahan tetapi pasti secara drastis mengurangi muatan ideologis mereka dalam rangka untuk meraih sebanyak mungkin jumlah pemilih. Partai politik di Indonesia mengalami perkembangan mengidentikkan diri sebagai catch all party. Sehingga, pembentukan dan pemeliharaan konstituen melalui ikatan ideologis tidak lagi menjadi agenda kerja partai.

Pilihan tersebut malah mengakibatkan berkurangnya ikatan hubungan partaipartai terhadap pemilih atau konstituennya. Sehingga, tak ayal menyebabkan dua hal yakni: pertama, dari sisi para pemilih atau konstituen semakin enggan untuk mengidentifikasikan diri (memudarnya Party ID) dengan partai yang sama selama dalam suatu siklus pemilihan, dan terdapat kecenderungan yang kuat untuk mengubah identifikasi mereka dari pemilihan ke pemilihan berikutnya, tentunya menguntungkan partai-partai baru tidak hanya sebagai peserta pemilu semata tetapi kemungkinan besar dapat memperoleh kursi di DPR meski diberlakukan aturan ambang batas parlemen, seperti fenomena partai politik Demokrat, Nasdem, dan sebagainya; maka hal ini tentu saja menunjukkan lemahnya ikatan antara partai dan konstituennya. Kedua, celakanya, yang kemudian tumbuh di era pasca reformasi ini adalah "partai mengambang," bahkan efektivitas partai politik cenderung tidak bertanggungjawab dan tidak tanggap terhadap konstituennya.

Ini pula yang turut mengkonfirmasikan berbagai penafsiran bahwa institusionalisasi partai politik di Indonesia pasca reformasi adalah masih lemah. Sehingga, yang terjadi adalah perkembangan dan peran partai politik secara internal sebagai infrastruktur politik belum dapat berkontribusi maksimal, akhirnya persepsi masyarakat terhadap kinerja partai politik tidaklah positif, masyarakat merasa tidak puas akan kinerja dari partai politik.

\section{Kesimpulan}

Perkembangan dan peran partai politik pada era reformasi ini mengalami dilematis. Di satu sisi, eksistensi partai politik semakin diakui sangat penting dalam UUD 1945 hasil amandemen, utamanya dalam soal rekrutmen penyelenggaraan negara. Namun, partai politik yang memiliki peran signifikan itu sebagai infrastruktur politik justru mengalami permasalahan. Sebab, pasca reformasi ini belum memperlihatkan kemajuan malah cenderung mengarah pada defisit demokrasi yang disumbang oleh partai politik, yang berdampak terhadap lembaga DPR. Perkembangan dan peran partai politik sekarang ini kurang responsif terhadap masyarakat maupun konstituen partainya, disebabkan partai-partai di Indonesia perlahan tetapi pasti secara drastis mengurangi muatan ideologis mereka dalam rangka untuk meraih sebanyak mungkin jumlah pemilih. Partai politik di Indonesia mengalami perkembangan mengidentikkan diri sebagai catch all party. Sehingga, pembentukan dan pemeliharaan konstituen melalui ikatan ideologis tidak lagi menjadi agenda kerja partai.

Pilihan menjadi partai catch all malah mengakibatkan berkurangnya ikatan hubungan partai-partai terhadap pemilih atau konstituennya. Fakta dan persepsi publik terhadap partai politik adalah rakyat merasa tidak dekat dengan partai politik. Ini terjadi dikarenakan institusionalisasi partai politik yang lemah, sehingga pola rekrutmen partai politik dilakukan dengan tidak transparan dan transaksional hanya untuk mengejar kepentingan elektoral semata, hal ini menyebabkan risiko terjadinya krisis kepercayaan rakyat atas partai politik disebabkan oleh jenjang kader yang tidak terencana dengan baik, sehingga banyaknya kader partai politik terjerat kasus korupsi; dan sejumlah pelanggaran etika yang dilakukan kader partai politik. Di sisi lain, pengelolaan institusional 
kepartaian yang lemah menyebabkan terjadi lemahnya kepercayaan masyarakat terhadap partai politik; kepemimpinan partai yang bermasalah; demokrasi internal partai yang tidak berjalan dengan baik; dan menguatnya politik dinasti di sejumlah partai politik. Itulah beberapa hal sorotan atau persepsi masyarakat terhadap perkembangan dan peran partai politik di era reformasi ini.

Oleh karena itu, diperlukan upaya serius untuk mewujudkan suatu kesadaran bersama utamanya para pemimpin partai pada era reformasi dewasa ini untuk segera membenahi diri. Para politisi dan elite partai tidak boleh malah terkesan berupaya melestarikan problematika struktural partaipartai dan "menikmati" situasi tidak sehat tersebut demi kelangsungan kekuasaan pribadi dan/atau kelompoknya semata. Penguatan institusionalisasi partai menjadi pekerjaan rumah bukan saja elite partai dan anggota internalnya tetapi juga harus adanya dorongan yang kuat dari masyarakat sipil, kita harus mulai mendorong bahwa penguatan institusionalisasi partai politik dengan cara: menuntut partai politik untuk menjadikan ideologi partai sebagai dasar penentu program dan strategi perjuangan partai tersebut; melembagakan kaderisasi dan rekrutmen politik yang transparan dan berdasarkan merit system; melembagakan aturan main partai politik yang konsisten dalam regulasi secara internal dan regulasi dari negara; dan mendorong terciptanya partai politik yang terbuka dalam regenerasi di tingkat internal partai politik tersebut.

Di samping itu, upaya pembenahan juga dalam konteks sistem kepartaian, pasca Pemilu 2019 ini, mulai dipikirkan bahwa harus disudahi tak ada jelasnya arah dan format, dalam perdebatan serius di kalangan elite-elite partai di Senayan, sudah semestinya dipikirkan dan diperdebatkan bahkan dirumuskan ke mana sesungguhnya arah sistem kepartaian pasca Orde Baru yang kita inginkan bersama. Jangan sampai terlalu lama dibiarkan, sehingga yang muncul seperti sekarang ini adalah upaya-upaya pragmatisme partai politik saja dalam mendulang suara dalam pemilu, hal ini malah menunjukkan bahwa partai politik hanya mengenai urusan memerintah semata dan/atau merebut dan mempertahankan kekuasaan politik, hasilnya adalah defisit demokrasi ini tumbuh sejak kepercayaan publik terhadap politisi maupun institusi politik menurun, banyak partai dan wakil rakyat (representative in democracy system) yang kehilangan hubungan dengan yang diwakili (represent).

\section{DAFTAR PUSTAKA}

Amal, Ichlasul, ed., Teori-Teori Mutakhir Partai Politik (Edisi Revisi), Yogyakarta: Tiara Wacana Yogya, 1996.

Apinino, Rio, "Membedah Potensi Golput di Pilpres 2019," Tirto.id, 12 Agustus 2018, diakses 14 Maret 2019, https://tirto.id/ membedah-potensi-gelombang-golput-dipilpres-2019,cRYi

Asshiddiqie, Jimly, "Penguatan dan Penataan Partai Politik di Masa Depan,” Jurnal Ketatanegaraan, no. 05, (November 2017).

Arifin, Anwar, Pencitraan dalam Politik (Strategi Pemenangan Pemiludalam PerspektifKomunikasi Politik), Bandung: Pustaka Indonesia, 2006.

Arikunto, Suharsimi, Prosedur Penelitian Suatu Pendekatan Praktek (Edisi Revisi), Jakarta: Rineka Cipta, 2002.

Azwar, Rully Chairul, "Partai Politik Ditengah Ancaman "Virus" Oligarki dan Politik Kartel," Jurnal Ketatanegaraan, no. 05, (November 2017).

Budiardjo, Miriam, Dasar-dasar Ilmu Politik (Edisi Revisi), Jakarta: Gramedia, 2008. 
Budiarti, Aisyah Putri, Personalisasi Partai Politik di Indonesia Era Reformasi, Jakarta: Yayasan Obor Indonesia, 2018.

Duverger, Maurice, Partai Politik dan Kelompokkelompok Penekan, penerj. Laila Hasyim, Bina Aksara, 1984.

Efriza, "Reformasi Kepartaian di Indonesia," Radar Sulbar, 21 Oktober 2014.

Ekawati, Esty, "Pandangan Ahli Pemetaan Kondisi Politik, Ekonomi, Sosial Budaya, Pertahanan dan Keamanan Menjelang Pemilu Serentak 2019,” makalah disajikan pada pertemuan untuk penyampaian rilis hasil Survei Ahli oleh LIPI, di Hotel JS Luwansa, Selasa 7 Agustus 2018.

Ellwin, Warsito dan Subagyo, Hari, Konstituen Pilar Utama Partai Politik, Jakarta: Friedrich Naumann Stiftung, 2011.

Faiz, Ahmad, "Survei: DPR dan Partai Tidak Dipercaya Publik," Koran Tempo, 15 Agustus 2016.

Faiz, Ahmad, "Survei: Partai Politik Semakin Tak Dipercaya," Koran Tempo, 23 Maret 2017.

Fatah, Eep Saefulloh, "Gejala Partai Mengambang,” Kompas, 18 November 2006.

Fatah, Eep Saefulloh, Pengkhianatan Demokrasi ala Orde Baru: Masalah dan Masa Depan Demokrasi Terpimpin Konstitusional, Bandung: Remaja Rosdakarya, 2000.

Haris, Syamsuddin, Partai, Pemilu, dan Parlemen Era Reformasi, Jakarta: Yayasan Pustaka Obor Indonesia, 2014.

Heywood, Andrew, Politik (Edisi Keempat), Yogyakarta: Pustaka Pelajar, 2014.

Ishiyama, John T., dan Breuning, Marijke, ed., Ilmu Politik Dalam Paradigma Abad Ke-21 (Jilid 1), Jakarta: Kencana, 2013.

Kartawidjaja, Pipit R., dan Kusumah, Mulyana W., Kisah Mini Partai Politik (Jakarta: Closs dan 7 Strategic Studies, 2003).
Katz, Richard S., dan Crotty, William, Handbook Partai Politik, Bandung: Nusamedia, 2015.

Labolo, Muhadam, dan Ilham, Teguh, Partai Politik dan Sistem Pemilihan Umum di Indonesia: Teori, Konsep dan Isu Strategis, Jakarta: RajaGrafindo Persada, 2015.

Laporan Survei di presentasikan pada 12 September 2017, yang dilakukan oleh Centre for Strategic and International Studies (CSIS), diakses 20 April 2019, https://www.csis.or.id/uploaded_file/ event/pemaparan_hasil_survei_opini_ publik_tiga_tahun_pemerintahan joko_widodo___jusuf_kalla__kinerja_ pemerintahan_dan_peta_politik_ nasional__notulen.pdf

Lisfianti, Widya, dan Dahwilani, Dani, "90 Persen Pilkada Berpotensi Jadi Tersangka," iNews, 07 Maret 2018, diakses 25 Februari 2019, http://www.inews.id/multimedia/ $\mathrm{read} / 90$-persen-peserta-pilkada-berpotensijadi-tersangka?sub_slug=video

Madira, Salman, "Selain Ketum PPP Romi Ini 4 PemimpinParpolyangPernahDitindakKPK karena Korupsi,” 15 Maret 2019, diakses 15 Maret 2019, https://news.okezone.com/ $\mathrm{read} / 2019 / 03 / 15 / 337 / 2030483 /$ selainketum-ppp-romi-ini-4-pemimpin-parpolyang-pernah-ditindak-kpk-karena-korupsi

Ma'shum, Saifullah, DPR Terhormat DPR Dihujat: Refleksi Lima Tahun di DPR Periode 2004-2009 (Catatan Sejarah Sang Wakil Rakyat), Jakarta: Kreasi Cendekia Pustaka, 2012.

Marijan, Kacung, Sistem Politik Indonesia: Konsolidasi Demokrasi Pasca-Orde Baru, Jakarta: Kencana, 2010.

Mukhtar, Umar, dan Hazliansyah, "Survei TII: DPR Lembaga Terkorup," Republika, 08 Maret 2017, diakses 26 Februari 2019, http://nasional.republika.co.id/berita/ nasional/umum/17/03/08/omgr7y280. survei-tii-dpr-lembaga-terkorup 
Nazir, M., Metode Penelitian, Jakarta: Ghalia Indonesia, 2003.

Noor, Firman, Quo Vadis Demokrasi Kita? Sebuah Respon Terhadap Konsolidasi Demokrasi Indonesia, Jakarta; RMBooks, 2015.

Pilliang, Indra J., "Kebangkitan 'Partycracy," Koran Jakarta, 27 September 2014.

Pradjasto, Antonio, "Partai Politik tak Hanya Kemampuan Memerintah", Jurnal Jentera, no. 16, (Juni 2007).

Romli, Lili, Problematik Institusionalisasi Partai Politik di Era Reformasi, Jakarta: LIPI, 2017.

Romli, Lili, Mencari Format Sistem Kepartaian Masa Depan, Jurnal Politika, no. 2, (2006).

S., Susanti Agustina, Suryaningtyas, Toto, dan Litbang Kompas, "Jajak Pendapat "Kompas" Mencari Penanda Wakil Rakyat," Kompas, 31 Juli 2017.

Salang, Sebastian, Potret Partai Politik di Indonesia: Asesmen terhadap Kelembagaan, Kiprah, dan Sistem Kepartaian, Jakarta: Friedrich Naumann Stiftung, 2007.

Skala Survei Indonesia, "Hasil Nasional tentang Kinerja Partai Politik dan Anggota Legislatif," Oktober 2012.

Sulardi, "Kemunduran Demokrasi," Koran Tempo, 24 Mei 2017.

Surbakti, Ramlan, Memahami Ilmu Politik, Jakarta: Gramedia, 1999.

Wibowo, Pramono Anung, Mahalnya Demokrasi Memudarnya Ideologi: Potret Komunikasi Politik Legislator-Konstituen, Jakarta: Kompas, 2013. 